This item was submitted to Loughborough's Research Repository by the author.

Items in Figshare are protected by copyright, with all rights reserved, unless otherwise indicated.

\title{
Global sport power Europe? The efficacy of the European Union in global sport regulation
}

\section{PLEASE CITE THE PUBLISHED VERSION}

http://dx.doi.org/10.1111/jcms.12512

\section{PUBLISHER}

(c) University Association for Contemporary European Studies and Wiley

\section{VERSION}

AM (Accepted Manuscript)

\section{PUBLISHER STATEMENT}

This work is made available according to the conditions of the Creative Commons Attribution-NonCommercialNoDerivatives 4.0 International (CC BY-NC-ND 4.0) licence. Full details of this licence are available at: https://creativecommons.org/licenses/by-nc-nd/4.0/

\section{LICENCE}

CC BY-NC-ND 4.0

\section{REPOSITORY RECORD}

Garcia, Borja, and Henk-Erik Meier. 2019. "Global Sport Power Europe? the Efficacy of the European Union in Global Sport Regulation”. figshare. https://hdl.handle.net/2134/22916. 


\title{
Global sport power Europe? The efficacy of the European Union in global sport regulation
}

Borja García, School of Sport, Exercise and Health Sciences; Loughborough University, UK. B.garcia-garcia@lboro.ac.uk

Henk Erik Meier; Institute for Sport and Exercise Sciences; Department of Social Sciences, University of Münster, Germany, Henk.Erik.Meier@uni-muenster.de

\begin{abstract}
The effectiveness of the European Union (EU) as global regulator is controversial. Some scholars characterize the EU as one of the most important shapers of global regulations; others argue that the EU's effectiveness critically depends on its regulatory cohesion, the political opportunity structure and regulatory capacity of its interlocutors. Since global sport represents a regionally segmented industry and is governed by private actors of diverse regulatory capacity, global sport regulation represents an excellent domain to study these propositions systematically. Comparative case studies on global sport regulation support the idea that the EU can impose its regulatory ambitions on sport governing due to market size and regulatory capacity. However, the broader political opportunity structure is found to be relevant and the EU does not appear as a strong regulator of global sports.
\end{abstract}

(C) Borja García and Henk Erik Meier 2016

Published in Journal of Common Market Studies.

Cite as: García, B., Meier, H.E. (2016) 'Global sport power Europe? The efficacy of the European Union in global sport regulation’, Journal of Common Market Studies, DOI 


\section{Introduction}

The single market represents the most salient presence of the European Union (EU) in the international system (Dür and Zimmermann, 2007). The EU has been characterized as great 'market power' (Damro, 2012) effectively shaping global regulation (Bach and Newman, 2010). The EU's success has been attributed to the size of its internal market and comparative advantage in regulatory capability. However, Young (2011) has recently challenged the EU’s image as influential global regulator by claiming that the EU's success hinges on the regulatory capability of its interlocutors and congruence with their preferences.

The research presented here contributes to this debate by focusing on the EU's success as global regulator of sports. Sport represents a critical case for examining the EU's effectiveness because the EU's market size varies considerably. Moreover, global sport regulation by public authorities is hardly institutionalized. Furthermore, sport is a hybrid sector, where low regulatory cohesion is likely. Nevertheless, the EU has acquired a reputation for being one of the few public authorities to influence sport regulation (Meier and García, 2015; Geeraert and Drieskens, 2015). It has been argued that the EU did not want to get involved in regulating sport but ended up doing it through the application of single market policies to sport and reacting to judgments of the Court of Justice (García 2007). However, through the involvement of different EU institutions and external actors evolving through legal decisions, political declarations and other non-binding reports and communications (Parrish, 2003; Geeraert and Drieskens, 2015), a distinctive regulatory approach to sport although not necessarily a deliberate policy by the EU seems to have evolved. 
Building on previous accounts (Young, 2011; Dür and Zimmermann, 2007; Bach and Newman, 2010), the following set of questions is explored:

1. Which objectives can be identified in the EU regulatory approach to global sport?

2. Is the EU able to attain regulatory cohesion?

3. How effective is the EU in accomplishing its objectives?

After a review of the literature and a presentation of the research design, the results of four cases where EU institutions were involved in global sport regulation are presented.

\section{The EU's success as global regulator}

Scholars have presented a number of complementary rather than competing propositions for explaining the EU's success as global regulator:

1. Market size. Since the EU represents the world's biggest internal market and is the largest exporter and importer of goods and services (Young, 2011; Young and Peterson, 2013), it enjoys 'structural power' in world trade allowing the EU to globalize its regulatory standards (cf. Meunier and Nicolaïdes, 2006; Dür and Zimmermann, 2007).

2. Regulatory capacity and cohesion. According to Bach and Newman (2007), the EU's success as global regulator results from its superior regulatory capacity. Thus, the EU's character as a 'regulatory state' creates a comparative advantage providing 'tools to set market rules internationally as well' (Bach and Newman, 2007, p. 828). However, whereas Bach and Newman (2007) deem regulatory cohesion to be beneficial, it has been emphasized that low cohesion might strengthen the EU's bargaining position in case the EU is on the defensive because the EU's high 
threshold for internal agreements prevents EU negotiators from making concessions (Meunier and Nicolaïdis, 2006; Young, 2011).

3. Regulatory politics. According to the 'regulatory politics' approach, an interplay of domestic and global factors accounts for the rise of the EU as global regulator (Kelemen and Vogel 2010; Kelemen, 2010). Hence, the fundamental tension between rules designed to perfect the single market and the global competitiveness for producers outside that market (Smith, 2011) can only be reconciled by uploading EU standards (Jacoby and Meunier, 2010).

4. Political opportunity structure. Young (2011) has stressed that previous research neglected that the EU's success depends not only on the EU's regulatory capability but also on (a) the regulatory capability of its interlocutor(s) and (b) how the EU's regulatory preferences align with those of non-EU governments.

Accordingly, our empirical account explores to what extent these explanations might be relevant for understanding the EU's success as global sport regulator.

\section{Peculiarities of global sport regulation}

Building on a rather narrow traditional understanding of regulation as economic regulation (e.g. Young, 2007, p. 374), global sport regulation by the EU might be tentatively defined as the EU adoption of decisions and rules aimed at professional sports intended to correct market failures, which applies also beyond the EU's borders. However, it is important to realize that sport policy pursues aims beyond the efficient provision of sport entertainment, such as, broad participation and inclusion in physical activity for reasons of public health and integration. Due to the clash of policy agendas (cf. below), even the EU's involvement in global sport regulation cannot be reduced to economic goals. Indeed, one of the characteristics of the EU's 
approach to sport is its 'Janus-faced' nature, where economic and socio-cultural elements have interacted.

In addition, professional sport shows some peculiarities:

1. Strong market segregation. Only the Olympics and football (soccer) may claim global popularity. Whereas North America and Europe represent the two biggest sport markets (PWC, 2011), even here market power is segregated. Between 2010 and 2012 European markets accounted for $22 \%$ of the broadcasting income of the International Olympic Committee (IOC) whereas North America accounted for 55.9\% (IOC, 2013, p. 27). In contrast, $49.6 \%$ of the Fédération Internationale de Football Association (FIFA)'s broadcasting income in 2012 and 2013 came from Europe but only 10.5\% from North America (FIFA, 2013, p. 100). Yet, global revenues for soccer are higher than combined revenues for all U.S. sports, Formula 1 racing, tennis and golf (A.T. Kearney, 2011).

2. Diffuse character and low capability. International sport governance has been diffuse and shaped by organizational rivalries, for example between the IOC and the International Federations (IFs), which govern the distinct sports. Moreover, the IFs share governance responsibilities with a broad range of stakeholders (leagues, clubs, athletes, organizers, etc.). Additionally, sport has been perceived as an autonomous sphere where political interference should be avoided (Chappelet 2010). The EU's ambitions to impose regulatory standards are likely to be perceived as particular interventionist or 'deep trade agenda' challenging incumbent regulatory authorities (Young and Peterson, 2006; Damro, 2006) because global professional sport relies on a complex and interwoven set of regulations. Thus, the EU might have to deal with interlocutors of only restricted regulatory capability and hostile to any public intervention (García and Weatherill, 2012). 
3. Clash of policy agendas and low cohesion. While professional sport represents an entertainment industry, Europeans perceive it as a much larger and deeper grassroots movement relying on volunteering and creating social capital. Hence, sport's hybrid character has given rise to a political agenda critical of market-oriented sport regulation (Parrish, 2003; Croci, 2009).

Thus, the EU's market size in sport varies considerably, regulatory efforts are likely to be perceived as invasive, and diffuse governance structures restrict the regulatory capacity of those same stakeholders. Finally, sport's hybrid character makes low policy cohesion likely.

\section{Case selection and method}

Preferably, the cases examined should have been selected in order to test the competing explanatory approaches, that is, market size, regulatory capacity, regulatory politics and political opportunity structure. Unfortunately, the population of cases is rather limited. Thus, it proved difficult to systematically control for market size even though both soccer and non-soccer related cases are included. Therefore, case selection follows the main rationale to focus on different regulatory ambitions. Accordingly, cases are examined where the EU aimed to (a) impose its governance standards on sport governing bodies, (b) protect athletes (c) and protect consumers. The organization of the case studies follows Young and Peterson (2013) and focuses on key variables, that is, i) political opportunity structure, ii) regulatory capacity and cohesion, iii) regulatory politics/processes and iv) outcomes. Yet, while careful process tracing has been employed, space restrictions allow only presenting highly stylized facts. 
Political opportunity structure is defined as the degree to which EU's regulatory preferences align with those of (a) other governments and (b) the sport governing bodies. Regulatory capacity and cohesion is understood as multidimensional construct comprising of (a) regulatory expertise, (b) coherence, and (c) the extent of statutory sanctioning authority (Bach and Newman, 2007). However, it seems useful to distinguish between a horizontal and vertical dimension (Smith, 2004). Concerning the horizontal dimension, regulatory capacity and cohesion refers first to the legal base of the EU's regulatory activities, second to the existence of competing agendas at the EU level. The vertical dimension regards the conformity of Member States’ policies with the EU's regulatory ambitions. Tracing regulatory politics/processes serves to assess the EU's impact on the regulations at stake. The outcomes of the regulatory processes will be assessed in terms of 'preference attainment'.

\section{Imposing governance standards:}

\section{The creation of the World Anti-Doping Agency (WADA)}

Doping has been perceived as a violation of fairness and a health threat, which could detrimentally affect the broader society due to the athletes' status as role models (Dimeo, 2007). Although the sport governing bodies have condemned doping, they failed to effectively address the problem, which ultimately led to the creation of WADA.

\section{Political opportunity structure}

Alignment with non-EU government's preferences: The cold war inspired highly sophisticated doping systems and made credible governmental cooperation in antidoping impossible (Hunt, 2007, p.19). The collapse of communism removed these 
barriers for cooperation and increased pressure on sport authorities to intensify antidoping efforts (Houlihan, 2002; Hunt, 2011). Finally, the so-called Festina scandal during the 1998 Tour de France catalyzed an unprecedented international governmental consensus on the inefficiency of the existing control system (Hanstad, Smith and Waddington, 2008).

Alignment with sport bodies' preferences: Doping policies represent a classic example of sport's self-regulation (Houlihan, 2002). However, diffuse international sport governance prevented regulatory harmonization and effective tests. The IOC failed as regulatory authority because some IFs were not strongly dedicated to antidoping (Hunt, 2011). National sport federations at least tolerated doping practices (Houlihan, 2002). Finally, the IOC made financial vitality a top concern in the 1980s and decreased its commitment to anti-doping (Hanstadt et al., 2008; Hunt, 2011). Although governments increased demands for stricter anti-doping policies in the 1990s, sport bodies resisted as much as they could any external regulatory agenda.

\section{Regulatory capacity and cohesion}

Legal mandate: Lacking a sport competence, the EU was hardly a visible actor in anti-doping policies before the Festina scandal (Vermeersch, 2006). Only after being asked by the Council (OJ, 1992, C 44/1), the Commission drafted an unambitious Code of Conduct heavily relying on Council of Europe initiatives (SEC (91) 2030 Final).

Competing agendas at EU level: Notwithstanding broad support for stricter global anti-doping policies among the Member States, a stronger EU involvement competed with the Member States’ concerns about supranational competence creeping. 
Vertical conformity with Member States' policies: Although the Member States followed different regulatory trajectories, they cooperated in the Council of Europe (CoE), which had assumed leadership in anti-doping policies since the 1970s. The 1984 CoE Anti-Doping Charter recommended public authorities to support the harmonization, implementation and enforcement of anti-doping regulations (CoE, 1984). The Charter was endorsed by the IOC, the United Nations Educational, Scientific and Cultural Organisation (UNESCO) and the World Health Association (WHO) (Houlihan, 2002, p.160) and resulted in the first World Conference on Doping in Sport held in Ottawa in late June 1988, which proposed stronger cooperation between sports authorities and national governments (Hunt, 2011, p.83). This demand was taken on in the CoE's Anti-Doping Convention of 1989 (CoE, 1989). After the Festina scandal, the EU sports ministers, the European Council, the European Parliament and the Committee of the Regions called on the Commission to make proposals for a more harmonized public health policy addressing doping (Vermeersch, 2006).

\section{Regulatory politics/processes}

The decisive steps towards far-reaching policy innovations were taken at the 'World Conference on Doping in Sports’ hosted by the IOC in Lausanne in February 1999. Whereas the IOC intended to regain control of the doping issue, representatives from the UK, the U.S.A. and Germany took the opportunity to blame IOC leadership for an inconsequent and hypocritical approach towards doping (Hanstad et al., 2009). The criticism converged around a demand for jurisdictional segregation and the creation of a new independent body: WADA (DeFrantz, 2008). 
The Commission's plan against doping (COM (1999) 643 Final) presented after the Lausanne conference included a commitment to the WADA process. The Commission claimed to have been decisive for securing organizational independence and transparency of WADA, parity between public and sport authorities and the submission of all involved parties to norms, criteria and procedures of WADA (European Commission, 1999). Moreover, the Commission acted (together with a representative from the EU Presidency) for two years as EU representative in the WADA Foundation Board (OJ, 2000, C 356).

\section{Outcome}

The creation of WADA enabled European governments to attain long-held policy preferences. The Second World Conference on Doping in Sport in 2003 drafted the World Anti-Doping Code (WADC) achieving an unprecedented level of global regulatory harmonization. Moreover, as it was agreed to create an International AntiDoping Convention under the auspices of UNESCO, the WADA regime has a solid base in international law and a much more aggressive mandate to mitigate doping (Hunt, 2011, p.87). The WADA process catalyzes also institutional isomorphism since governments are required to emulate the WADA structure and to create national anti-doping organizations (NADOs).

However, in relation to its share in WADA funding (47.5\%), the EU seems underrepresented in WADA's Foundation Board (3 members out of 15). Furthermore, the WADA process failed to serve as catalyst of a more structured antidoping policy within the EU. Finally, the Commission withdrew from WADA in 2001 because the lacking EU competence in sport made it impossible to reconcile the WADA budgetary rules with Community financial rules (European Commission, 
2001). After 2009, now with a formal competence on sport, the EU is developing a minimum common approach to anti-doping and WADA. However, there is clearly no appetite for direct regulation and most actions focus on amateur sport (De Wolff, 2016).

\section{Protecting athletes' rights: Liberalizing the player market}

As the soccer bodies traditionally opposed professionalization and perceived deregulated player markets as economic threat, they placed players at the bottom of a decision-making pyramid headed at the top by the game's global governing body, FIFA (Tomlinson, 1983). Regulations adopted by FIFA (at global level) or the Union of European Football Associations (UEFA) (at European level) are applied in cascade at national level. FIFA and UEFA's regulation of players' employment relied in two sets of norms: transfer systems and nationality quotas (Lanfranchi and Taylor 2001, p.218).

EU institutions started to notice tension between player market regulations and the freedom of movement for workers since the 1980s. However, they took a rather conciliatory stand (García and Meier, 2012). It was not until the 1995 judgment of the Bosman case that a real regulatory effort by the Commission took place. This case study focuses on the actions between December 1995 and 2001, when the Commission reached an agreement with UEFA and FIFA on the reform of their international transfer system.

In Bosman the Court of Justice of the European Union (CJEU) ruled that both the international transfer system, in particular the requirement to pay transfer fees even after the end of the payer's contract, and nationality quotas were in breach of 
freedom of movement provisions (CJEU 1995). Not long after the Bosman ruling, the Commission addressed a warning letter to UEFA and FIFA giving them six weeks to inform of the measures they were taking to comply with Community law (European Commission, 1996b, p. 1).

\section{Political opportunity structure}

Alignment with non-EU government's preferences: Although a number of countries exported players to other EU countries, they did not take a visible stance on the player market conflict.

Alignment with sport bodies' preferences: FIFA and UEFA continued to be hostile to any player market liberalization. After Bosman, they informed the Commission that the international transfer system would no longer apply to player movements within the European Economic Area (EEA) but that the rules were not officially revoked (European Commission, 1996a). Moreover, the clubs responded by extending contract durations and increasing fees for player transfers during the contract period. The governing bodies opposed the full liberalization of the players market as demanded by the Commission (Bose, 2000). Governing bodies, with the support of European professional leagues, wanted to preserve stability of contracts as much as possible and to re-label transfer fees as 'training compensation fees' so clubs could still receive payment for player transfers (Bose 2000; European Commission 2000; Meier and García 2013; García and Meier 2012).

\section{Regulatory capacity and cohesion}


Legal mandate: The legal mandate for this regulatory effort was strong, as the European Commission, and especially the Directorate General for Competition (DG COMP), was relying on a firm ruling of the CJEU (1995). The Commission, thus, was acting on safe grounds, as it is responsible to ensure compliance with EU primary and secondary legislation. Moreover, the Commission launched this investigation under competition policy regulations, a domain where it enjoys a wide power and autonomy.

Competing agendas at EU level: The Commission faced political opposition, even internally. According to Parrish (2003, p. 251), this opposition resulted from the emergence of two competing 'advocacy coalitions' after Bosman. A 'single market coalition', formed by DG COMP, the Parliament's Committee on Legal Affairs and Citizen Rights and the Court of Justice demanded considering sport a business like any other. In contrast, a 'socio-cultural coalition' demanded a special treatment of sport even at professional level. This socio-cultural coalition featured the Directorate General for Education and Culture (DG EAC) in the Commission, high-level members of the Party of the European Socialists in the Parliament, sport governing bodies and, importantly, 'most of the Member States governments' (Parrish, 2003, p. 251). Yet, Croci (2009) has argued that the EU has always pursued two contradictory objectives in the field of sport: the correction of market failures of professional sport and the maintenance of sport as a social, cultural, health and educational activity. The clash of these two agendas is reflected in the Amsterdam Declaration on Sport, which called 'on the bodies of the European Union to listen to sports associations when important questions affecting sport are at issue’ (European Council, 1997).

Vertical conformity with Member States' policies: Although Member States opposed player market liberalization at EU level, most of the large countries in 
Europe had already liberalized their national transfer systems well before 1995 . The tendency towards liberalization of national soccer markets might explain why the Member States were never completely behind the position of FIFA (Meier and García, 2013). Nevertheless, most Member States declared to be concerned about an excessive liberalization of the players market. The differences between Commission and Member States became evident once formal proceedings were launched. On 9 September 2000 Tony Blair and Gerhard Schroeder published a joint statement that diplomatically supported UEFA and FIFA:

The British and German Governments are concerned at the potential impact of proposed changes to the football transfer system. (...) The European Union has criticised the present system of transfer fees (...) We acknowledge the current system is not perfect. We fear however that a radical reform could have a negative impact on the structures of football in Europe. (...) We believe that any solution has to balance carefully the justified interests of both the players, the clubs and the associations. (...) We offer our help in seeking to resolve the issue. (...) We look to the Commission to be sympathetic to the special needs of professional football in seeking a solution (Prime Minister's Office, 2000b, p. 1).

The British Prime Minister worked also with governments of Spain, the Netherlands and Italy to demonstrate disagreement with the Commission's liberalization plans (Prime Minister's Office, 2000a).

\section{Regulatory politics/processes}

Unhappy with the soccer bodies' response to Bosman, the Commission informed FIFA and UEFA on 27 June 1996 that two particular issues, on which the Court had not ruled in Bosman, posed extra problems in the light of article 101 TFEU 
(European Commission, 1996a, p. 5-6). After FIFA and UEFA refused to take those aspects into account, the Commission started infringement procedures on 14 December 1998 (European Commission, 2002, p. 1). The Commission addressed the payment of fees for international transfers within the EEA of players from third countries at the end of their contracts, and the obligation imposed by FIFA on national FAs to set up national transfer systems mirroring the one outlawed in Bosman (Parrish, 2003, p. 140-142). When FIFA remained inactive, the Commission defined a firm deadline of 31 October 2000 for proposals to amend the international transfer system (Reding, 2000, p. 2; Parrish, 2003, p. 141).

A Transfer Task Force with the participation of FIFA, UEFA, the international soccer players union (FIFPro), and European professional leagues was set up (UEFA, 2000). This Task Force agreed on a set of proposals on 27 October 2000, which were then sent to the Commission (Bose 2000). The Commission (2000: 1) was ready to accept rules limiting transfers to a certain period during the season and also recognised that 'stability of contracts is very important in this sector'. Finally, the Commission (ibid.) was prepared to consider the concept of 'training compensation fees' for young players. In 2001 a number of high level meetings between the commissioners responsible for the negotiations and the presidents of FIFA and UEFA were held, during which the two sides agreed on transfer windows, minimum and maximum duration of contracts and the principle of compensation for training costs (European Commission, 2001a, 2001b, 2001c). After the governing bodies agreed to these reforms (European Commission, 2001d), the Commission closed the investigation in June 2002 (European Commission, 2002b). 


\section{Outcome}

The demands of the Commission diluted considerably over time, which might be explained by the clash of competing agendas (Parrish, 2003) or the fact that the Commission employed negotiation as ‘mode of governance' (Croci, 2009). Actually, these two explanations might be rather complementary since there were indeed two different views of sport regulation within EU institutions and sport stakeholders, and the Commission navigated through them in its very common compromise and negotiation mode of governance. Nevertheless, FIFA was forced to undertake a significant reform of its transfer system, most importantly to limit maximum contract duration to five years and to abolish end-of-contract transfer fees. However, training compensation fees were allowed for transfers of players under 23 years, transfer periods were limited, minimum contract duration was defined as one year and solidarity mechanisms redistributing income to clubs involved in the training and education of soccer players were implemented. This settlement falls short of the liberalisation initially demanded by the Commission (Meier and García, 2013) and is beneficial for the governing bodies (Parrish, 2003, p. 147). However, as FIFA decided to apply these transfer rules globally (Drolet, 2006; FIFA, 2001), the EU accounts for a modest global player market liberalization.

\section{Protecting EU athletes' privacy}

Current anti-doping policies are rooted in a policy paradigm trying to eradicate doping by relying on effective surveillance of athletes, which inevitably raises the question of athletes' rights. Accordingly, the 2003 WADC introduced so-called 'whereabouts' rules demanding athletes to report on their location. Moreover, athletes had to be available for one hour per day between 6 a.m. and 11 p.m. to make 
'surprise' anti-doping tests possible. Three 'missed tests' were to be punished as a doping offense (WADA, 2003). In order to ensure transparency and global enforcement, an online system with athletes' whereabouts data stored in servers of the Anti-Doping Administration and Management System (ADAMS) was implemented.

However, the 2003 WADC left IFs and NADOs too much discretion (Halt, 2009; MacGregor et al., 2013) resulting in inconsistent implementation of this scheme (Hanstad et al., 2010; Houlihan, 2013). Therefore, WADA aimed at further harmonization for the 2009 revision of the WADC. WADA's 2008 draft for a new WADC and the International Standard for Testing (IST) demanded athletes to indicate, for each day during the following quarter, one specific 60-minute time slot for testing at a specific location (WADA, 2008, Art. 11.0). However, athletes were not going to be charged with a missed test if they could not be reached outside the one-hour slot (WADA, 2008, Art. 11.4).

WADA's plans were met with hostility by professional athletes and some governing bodies. The European Elite Athletes Association (EEAA) opposed the invasive character of whereabouts and demanded a stronger participation of athletes in the creation of drug testing regimes (EEAA, 2008). Athletes, individually, also complained of the severity of WADA's plans (cf. Valkenburg et al., 2014). Soccer's governing bodies FIFA and UEFA, as well as FIFPro, protested against privacy violations (FIFA, 2009; Slater, 2009). Crucially, these WADA proposals were criticized by EU actors claiming a violation of athletes' privacy rights and possible infringements of EU data-protection legislation (cf. Waddington, 2010; De Wolff, 2016). 


\section{Political opportunity structure}

\section{Alignment with non-EU government's preference: Data-protection concerns}

contradict the basic policy paradigm of anti-doping according to which doping can only be eradicated by increasing athletes’ surveillance. Thus, EU concerns on dataprotection were seen as slowing down the global anti-doping fight. Moreover, 'privacy’ does not represent a globally accepted legal concept (McGregor et al., 2013, 17-8). Thus, the EU faced substantial barriers to globalize its particular ambitious privacy standards (Drezner, 2004; Newman, 2008). With the exception of EU representatives, both the WADA Executive Committee and Foundation Board initially ignored EU’s concerns and demands (De Wolff 2016).

Alignment with sport bodies’ preferences: From the beginning, WADA left no doubts that it disapproved of the EU's demands.

\section{Regulatory capacity and cohesion}

Legal mandate: Anti-doping rules fall within the purview of EU law (Meca-Medina v. Commission of European Communities, 5 C.M.L.R. 18). The whereabouts system was in tension with a number of legal stipulations protecting athletes' rights within the EU, such as the European Convention of Human Rights, the Working Time Directive of 2003 (Council Directive 90/104, 1993 O.J. (L 307) 18 (EU)) and the European Data Protection Directive of 1995 (Council Directive 95/46, 1995, O.J. L281/13 (EC)) (Halt, 2009; McGregor et al., 2013).

Competing agendas at EU level: As already indicated, the EU faced a basic policy dilemma as promoter of stricter anti-doping polices and privacy protection. Hence, the EU failed to achieve regulatory cohesion. The EU Commissioner for Education, 
Training, Culture and Youth, Ján Figel, requested a legal opinion concerning the whereabouts system from the EU Working Party on Data Protection (WPDP). The WPDP did not coordinate with the European anti-doping policy community and seemed to promote uncompromisingly its own agenda, severely criticizing the data protection standards proposed by WADA for its new whereabouts system (cf. WADA, 2009b, p.3, 2009d, p.1).

Vertical conformity with Member States' policies: Since privacy and data protection regulations had been adopted by the Member States, privacy concerns were partially shared by the Member States, which also faced basic policy dilemmas.

\section{Regulatory politics/processes}

Whereas WADA signaled its unwillingness to compromise on the whereabouts system (Halt, 2009), it could not completely ignore EU's resistance and drafted an 'International Standard for the Protection of Privacy and Personal Information' (ISPPPI) (WADA, 2009b). The ISPPPI acknowledged that the WADC raised privacy concerns but aimed only at implementing minimum data protection rules (WADA, 2009b, Art. 1.0). Moreover, WADA claimed that its data policy was legitimized by the athletes' informed consent (WADA, 2009b, Art. 6.0).

In its response, the WPDP challenged central WADC stipulations. The WPDP established that the ISPPPI failed to meet EU data protection standards (WPDP, 2008, p.9) and demanded 'a valid legal ground', that is national legislation, for the whereabouts system (WPDP, 2008, 5). Moreover, the WPDP stated that a transfer of data from the EEA to a third country (i.e. Canada where the servers of ADAMS are located) could only take place if the third country ensured an adequate level of protection (WPDP, 2008, 6-7). Accordingly, the EU representative in 
WADA's Executive Committee tried to get WADA to postpone the adoption of the revised whereabouts system until data-protection problems were duly addressed (Waddington, 2010).

However, WADA revised the ISPPPI only in a very limited way (cf. WADA, 2009a; Buchner, 2009). The WPDP now radicalized its critique and 'disregard[ed] the WADC and International Standards insofar as they contradict domestic law' (WPDP, 2009, p.3). The WPDP renewed its demand of a public-body status for the NADOs and opposition to data transfer into low protection jurisdictions (WPDP, 2009).

This second WPDP opinion provoked a particularly harsh response by WADA (Waddington, 2010, p.262). WADA blamed the WPDP for 'undermine[ing] a critical pillar in the global strategy for combating anti-doping in sport' (WADA, 2009b, p.2) and ‘legislative imperialism’ (WADA, 2009d, p.15). WADA emphasized the WADC's mandate in international law (WADA, 2009d, p.20) and issued a counter-threat by announcing that if personal data of EU athletes could not be processed, these athletes would not be able to participate in organized sport (WADA, 2009d, p.17). Now, the EU gave in. EU and WADA only agreed to institutionalize the dialogue on privacy and data protection (European Commission, 2009). So far, the EU succeeded merely in convincing WADA to restrict publicity for data relating to minors (WPDP, 2013).

\section{Outcome}

The EU failed to globalize its paradigm for privacy and data protection in highperformance sports (Buchner, 2009), mostly due to its demands for high dataprotection standards, a competing policy paradigm and active opposition of WADA. 
Moreover, the ISPPPI, although a concession to EU's regulatory standards, is seen by specialists as a toothless minimum standard that includes no procedures for sanctioning any misconduct concerning confidential data on behalf of WADA (Trainor, 2010).

\section{Protecting sport consumers: Banning tobacco advertising}

In order to reduce smoking, the EU as well as other public authorities progressively restricted tobacco advertising. Inevitably, these efforts reached the sport domain as tobacco industry heavily sponsored sports because it could link its products to health, beauty and purity and circumvent advertising bans (Gradauskaite, 2010). In particular, Formula One (F1) entered a symbiotic relationship with tobacco firms (Grant-Braham and Briton, 2012).

\section{Political opportunity structure}

Alignment with other government's preference: As insights into adverse health effects of tobacco consumption grew, governments started restricting tobacco advertising (Cairney, 2007). In 1998, the WHO proposed an International Framework Convention for Tobacco Control (FCTC) recommending a total advertising ban (Hoek and Sparks, 2000).

Alignment with sport bodies' preferences: In contrast to IOC and FIFA, F1 fiercely opposed stricter regulations on tobacco advertising and threatened to relocate to other jurisdictions even though Europe was F1's key market. Thus, F1 joined the tobacco industry in its efforts to block advertising and sponsorship bans in the EU (Bitton et al., 2002). 


\section{Regulatory capacity and cohesion}

Legal mandate: The Commission was committed to stronger tobacco regulation and acted as EU lead negotiator in the FCTC process (Mamudu and Studlar, 2009). However, the Amsterdam Treaty of 1997 provided only a mandate to promote public health while building a single market but not to propose laws whose primary purpose was the advancement of public health (Duina and Kurzer, 2004). Hence, the Commission tried to circumvent its restricted legal mandate.

Competing agendas at EU level: Besides resistance by some Member States there existed no competing agendas at EU level.

Vertical conformity with Member States' policies: Regulatory cohesion among the Member States was low. A number of Member States had already released strict bans on tobacco advertising, others, in particular Germany, perceived the tobacco industry as important economic sector and blocked any EU bans (Duina and Kurzer 2004).

\section{Regulatory politics/processes}

Since Alegre (2003) as well as Duina and Kurzer (2004) have provided excellent accounts on the cumbersome legislative history of the first and second versions of the Tobacco Advertising Directive (TAD1 and TAD2 respectively), it suffices to refer basic process features. After the 1985 Directive on Television without Frontiers (89/552/EEC) banned tobacco advertising in audiovisual communications, a Council minority blocked further legislative progress until 1997 when TAD1 was adopted. TAD1 enacted in July 1998 banned tobacco advertising and sponsorship but allowed 
Member States to continue sponsorship of world-level events for an additional three years but not later than October 1st 2006.

Already before, F1 had turned to venues outside the EU and convinced them to allow tobacco sponsorship (Xue and Mason, 2011). F1 continued to threaten to quit the EU (Hoek and Sparks, 2000; Bitton et al., 2002). Moreover, F1 boss Bernie Ecclestone donated in $1998 £ 1$ million for the UK’s Labor Party election campaign. The Labor government allowed F1 to have tobacco sponsors in the UK races until October 2006, and voted against TAD2 (Cairney, 2007; Duina and Kurzer, 2004). Moreover, Germany and several British tobacco companies initiated legal actions against TAD1. The CJEU supported Germany's claim that TAD1 was mainly created to protect public health and, accordingly, annulled TAD1 (Germany v. Parliament and Council, 2000 E.C.R. 1-8419). However, the CJEU indicated how a ban would be valid. Thus, in May 2001, the Commission proposed a new directive, which was adopted by qualified majority in the Council. TAD2 specified no transitional period for sport sponsorship and was supposed to enter into force in July 2005 (cf. Alegre, 2003).

\section{Outcome}

TAD2 effectively ended business models in professional sport based on tobacco advertising and sponsorship. After 2006 most tobacco sponsorship of F1 came to an end (Grant-Braham and Briton, 2012). However, F1 did not abandon its EU sites as the problematic financial sustainability of racecourses made relocation difficult (Xue and Mason, 2013). 


\section{Discussion and conclusion}

This article aimed to discuss three dimensions of the EU's role in the regulation of global sport, as explained in the introduction.

Concerning the extent to which one may identify EU's aims in global sport regulation, the case studies leave the impression that the EU's ambitions are rather limited to the attempt to reconcile the EU's internal market regulations with the regulations of the international sport governing bodies. The only exception is antidoping where the EU aimed to impose governance standard. Thus, this is a rather reactive agenda mirroring the processes behind the evolution of sport regulation within the EU (García 2007). Thus, the EU’s main objectives were to iron out the incompatibilities between EU law and global sport regulations. The EU actions did not aim to directly regulate global sport. However, the EU pursues insofar a consistent regulatory approach as it does not hesitate to take on international sport governing bodies to ensure their policies abide by EU regulatory standards.

Yet, the EU faces considerable problems in attaining regulatory cohesion, though, which results from competing policy agendas (Parrish, 2003; Croci, 2009), diverging preferences among the Member States as well as policy fragmentation.

When reflecting the EU's efficacy, its limited ambitions should be considered. Moreover, it is useful to compare the case studies in the lights of the theoretically derived concepts guiding the narratives (cf. Table 1). 


\begin{tabular}{|c|c|c|c|c|}
\hline & WADA process & Player market & Privacy & Tobacco \\
\hline \multicolumn{5}{|l|}{$\begin{array}{l}\text { Political opportunity structure } \\
\text {. }\end{array}$} \\
\hline Alignment with non-EU governments & Very strong & Unclear & Very low & Very strong \\
\hline $\begin{array}{l}\text { Alignment with sport governing } \\
\text { bodies }\end{array}$ & Very weak & Very weak & Very weak & Very weak \\
\hline \multicolumn{5}{|l|}{ Regulatory capacity } \\
\hline Legal mandate & Weak & Very strong & Very strong & Weak \\
\hline Competing agendas at EU level & $\begin{array}{l}\text { Concerns about EU } \\
\text { competence creeping }\end{array}$ & $\begin{array}{l}\text { Competing sociocultural } \\
\text { agenda hostile to player } \\
\text { market liberalization }\end{array}$ & $\begin{array}{l}\text { Basic unresolved policy } \\
\text { dilemmas }\end{array}$ & $\begin{array}{l}\text { Concerns about EU } \\
\text { competence creeping }\end{array}$ \\
\hline Vertical conformity & Very strong & $\begin{array}{l}\text { Medium, as some } \\
\text { Member States had } \\
\text { already liberalized the } \\
\text { player market }\end{array}$ & $\begin{array}{l}\text { Strong but basic } \\
\text { unresolved policy } \\
\text { dilemmas at the Member } \\
\text { State level }\end{array}$ & $\begin{array}{l}\text { Strong resistance by some } \\
\text { Member States }\end{array}$ \\
\hline Regulatory processes & $\begin{array}{l}\text { Decisive impact of some } \\
\text { Member States, } \\
\text { Commission } \\
\text { participation in policy } \\
\text { drafting }\end{array}$ & $\begin{array}{l}\text { Decisive impact of EU, } \\
\text { interventions of Member } \\
\text { States against } \\
\text { Commission initiative, } \\
\text { watering down of } \\
\text { liberalization efforts }\end{array}$ & $\begin{array}{l}\text { Some impact despite EU } \\
\text { isolation }\end{array}$ & $\begin{array}{l}\text { Cumbersome due to } \\
\text { division of Member States, } \\
\text { active threats by sport } \\
\text { govering body }\end{array}$ \\
\hline Regulatory outcomes & $\begin{array}{l}\text { Achievement of major } \\
\text { European policy aims }\end{array}$ & $\begin{array}{l}\text { Limited global player } \\
\text { market liberalization }\end{array}$ & $\begin{array}{l}\text { Failure to globalize } \\
\text { privacy standards, only } \\
\text { limited regulatory } \\
\text { concessions }\end{array}$ & $\begin{array}{l}\text { Lagged implementation of } \\
\text { global standards }\end{array}$ \\
\hline
\end{tabular}


Political opportunity structure: All of the EU's regulatory ambitions were met with resistance by the sport governing bodies. Concerning other governments' preferences, the political opportunity structure was most favorable in the WADA process whereas the EU was isolated on privacy.

Regulatory capacity and cohesion: Policy cohesion was only high in the WADA process and had been established by the activities of the Council of Europe. In player market regulation the Commission possessed a robust mandate and strong procedural powers but competing policy agendas forced the Commission into compromises (García and Meier, 2013). Although whereabouts clearly conflicted with EU law, the EU did not manage to overcome the segregation of policy arenas. Finally, regulatory cohesion was lowest in case of tobacco regulation.

Regulatory politics/processes: The case studies indicate that the EU possesses some structural power in global sport regulation enabling the EU to force the sport governing bodies at least into some concessions.

Regulatory outcomes: With the exception of the creation of WADA, the EU failed to globalize its regulatory ambitions without making substantial concessions. However, the transfer regulations represent successful globalization of reduced and slightly contradictory ambitions. Concerning tobacco advertising, the EU was a policy laggard but managed to finally achieve its aims. Yet, the case of privacy represents a painful failure to globalize EU data-protection standards. Accordingly, it can be argued that the EU has been somehow influential in changing FIFA's transfer system and nationality quotas and banning tobacco sponsorship of F1, at least within its own regulatory realm (cases 2 and 4), but less effective in protecting athletes' rights (case 3). 
The EU's impact was highest when its preferences aligned with those of other key markets, in particular the U.S, and policy cohesion was high even in the absence of clear legal mandate. The IOC was not able to resist pressure for regulatory reforms emanating from its key markets. In contrast, the EU was completely isolated on the issue of athletes' privacy. In the case of player market regulation, the EU could push for substantial reforms on the base of a clear legal mandate. Thus, regulatory capacity appears to be a more-dimensional construct with high policy cohesion compensating to some extent for a clear legal mandate. In contrast, low regulatory capacity appears to be a crucial obstacle to regulatory success as privacy and tobacco regulation suggest. As stressed before, systematically controlling for variations in EU market size proved to be difficult. However, whereas the EU represents the central market for soccer and F1, regulatory outcomes differed substantially even though the F1 case suggests that relocation of sport events works only to some extent for sport governing bodies. Thus, it might be tentatively inferred that low regulatory capacity prevents the EU from making the best use of its structural powers. Hence, global sport regulation supports the traditional perspective according to which market size and regulatory capacity are important for globalizing the EU's regulatory ambitions and the slight revisionist view that the broader political opportunity structure matters. In contrast, regulatory politics/process explanations seem not very relevant. The EU did not try to 'upload' regulatory preferences out of concerns about producers' competitiveness. Rather, the EU's efforts were triggered by tensions between EU law and sport regulations (see also Croci, 2009).

Accordingly, it can be concluded that the EU's efficacy as global regulator of sport is limited, which reflects to some extent the EU's modest ambitions discussed above. While it might be emphasized that the EU was not (and has not) intended to 
regulate directly global sports, the combined dynamics of domestic market integration and external globalization make it likely for new regulatory issues to emerge, and for the EU to address them. Hence, increasing EU involvement in global sport policy might not be that exceptional. Moreover, this research is of broader relevance because in other sectors the EU is also confronted with private regulatory authorities and transnational corporations located outside the EU, which act as global regulators. Thus, global sport regulation illustrates the potential problems the EU faces in relation to these private regulators in case the EU lacks policy cohesion.

From the traditional trade policy perspective, the insight that the EU is not a strong regulator of global sports might at first glance not be very relevant. However, the EU has a vital economic and social interest in soccer not only because of the industry's relevance as media upstream market. By now, the professional game represents a flourishing export industry with the UEFA Champions League and top clubs as global brands (Deloitte, 2016). Thus, the EU has to be interested in protecting the industry's integrity, which is threatened by corruption as well as match fixing. Yet even in face of an 'objective' need to address governance failures, the EU has left it to U.S. judicial authorities to address blatant corruption in FIFA. Admittedly, FIFA is not residing in the EU and has proven to be difficult to control (see, e.g. Pielke, 2013; Geeraert and Drieskens, 2015). However, the EU has been one of the very few public bodies able to impose some regulatory change on FIFA (Meier and García, 2015). Given the economic and social importance of soccer, the EU should make better use of its structural power and regulatory 'ammunition' that other actors at national level do not have in relation to FIFA and international sport governing bodies. 


\section{Acknowledgments}

The authors would like to thank three anonymous reviewers whose constructive

comments helped to substantially improve the paper.

\section{References}

A.T. Kearney (2011). The sports market: Major trends and challenges in an industry full of passion. A.T. Kearney. http://www.atkearney.com/documents/10192/6f46b880-f8d14909-9960-cc605bb1ff34 [last accessed 18 May 2014].

Allegre, M. (2003). 'We've come a long way baby (or have we?): Banning tobacco advertising in the European Union.' Boston College International and Comparative Law Review, 26, 157-171.

Bach, D. and Newman, A. L. (2007) 'The European regulatory state and global public policy: micro-institutions, macro-influence', Journal of European Public Policy 14(6): 827-46.

Bach, D. and Newman, A. L. (2010), „Governing Lipitor and Lipstick: Capacity, Sequencing, and Power in International Pharmaceutical and Cosmetics Regulation, Review of International Political Economy, 17/4, 665-95.

Bitton, A., Neuman, M.D. and Glantz, S. (2002). Tobacco Industry Attempts to Subvert European Union Tobacco Advertising Legislation. San Franciso: Center for Tobacco Control Research and Education.

Bose, M. (2000) 'Players' rift with FIFA threatens transfer talks', The Daily Telegraph, 28 October 2000.

Buchner, B. (2009). Der gläserne Sportler. Datenschutz und Datensicherheit, 8, 475-479.

Cairney, P. (2007). A 'Multiple Lenses' Approach to Policy Change: The Case of Tobacco Policy in the UK. British Politics, 2, 45-68

Carolan, E. (2006). The new WADA Code and the search for a policy justification for antidoping rules. Seton Hall Journal of Sports and Entertainment Law, 16, 1-43.

Chappelet, J. L. (2010) Autonomy of Sport in Europe. Strasbourg: Council of Europe Publishing.

Council of Europe (1984). Recommendation No. R(84)19 of the Committee of Ministers to Member States on the 'European Anti-Doping Charter for Sport'. Strasbourg: CoE.

Council of Europe (1989). Anti-doping convention. Strasbourg: CoE.

Court of Justice of the European Union (1995) Judgment of the Court of 15 December 1995. Union royale belge des sociétés de football association ASBL v Jean-Marc Bosman, Royal club liégeois SA v Jean-Marc Bosman and others and Union des associations européennes de football (UEFA) v Jean-Marc Bosman. Case C-415/93, European Court Reports 1995 I-04921.

Croci, O. (2009) 'Taking the field: the European Union and sport governance' in I. Tömmel and A. Verdun (eds.), Innovative Governance in the European Union. The politics of multilevel governance, Boulder: Lynne Rienner, pp. 139-157

Damro, C. (2006). The new trade politics and EU competition policy: shopping for convergence and co-operation, Journal of European Public Policy, 13, 867-886.

Damro, C. (2012). 'Market power Europe.' Journal of European Public Policy, 19, 682-699.

De Wolff, M. (2016) 'Playing for the same team? The trio Presidency and agendamanagement in European Union sport policy', Unpublished $\mathrm{PhD}$ dissertation, Loughborough University.

DeFrantz, A.L. (2008). 'Which Rules: International Sport and Doping in the 21st Century.' Houston Journal of International Law, 31, 1-30.

Deloitte (2016). European football scores \$30 billion. London: Deloitte. 
Dimeo, P. (2007). A history of drug use 1876-1976: Beyond good and evil. London \& New York: Routledge.

Drezner, D.W. (2004). The global governance of the Internet: Bringing the state back in. Political Science Quarterly, 119, 477-498.

Drolet, J. C. (2006) 'Extra time : Are the new FIFA transfer rules doomed?' International Sports Law Journal, 1-2, pp. 66-74

Duina, F. and Kurzer, P. (2004) 'Smoke in your eyes: the struggle over tobacco control in the European Union.' Journal of European Public Policy, 11(1), 57-77.

Dür, A. (2011), „Fortress Europe or Open Door Europe? The External Impact of the EU's Single Market in Financial Services," Journal of European Public Policy, 18/5, 61935.

Dür, A. and Zimmermann, H. (2007). Introduction: The EU in International Trade Negotiations. Journal of Common Market Studies, 45, 771-787.

EEAA (2008). EU athletes position statement on anti-doping, 26. November 2008. http://www.euathletes.org/media-press/news-from-eu-athletes/eu-athletesnews/browse/27/article/doping.html?tx_ttnews[backPid]=361\&cHash=892910556216 f44794fb698962b41465 [last accessed 30 April 2014].

European Commission (1999). Communication from the Commission to the Council, the European Parliament, the Economic and Social Committee and the Committee of the Regions. COM(1999) 643 final.

European Commission (1996a) Note de la Dg4 Présentée à la Commission: Conséquences de L'arret Bosman; Affaire C 415/93 de la Court de Justice. SEC (1996) 212/1, 1 February 1996.

European Commission (1996b) Answer on Behalf of the Commission to Written Question P163/96 by Luigi Moretti (ELDR) OJ C112/1996, 17 April 1996, p. 70.

European Commission (2000) Football transfers: Commission underlines the prospect of further progress, European Commission Press Release. IP/00/1417, 6 December 2000. Available online at:

http://europa.eu/rapid/start/cgi/guesten.ksh?p_action.gettxt=gt\&doc=IP/00/1417|0|RA PID\&lg=EN

European Commission (2001). Community funding of the operating budget of the World Anti-Doping Agency has been ruled out. IP/01/1727, 3 December.

European Commission (2001a) Joint statement by Commissioners Monti, Reding and Diamantopoulou and Presidents of FIFA Blatter and of UEFA Johansson, European Commission Press Release. IP/01/209, 14 February 2001. Available online at: http://europa.eu/rapid/start/cgi/guesten.ksh?p_action.gettxt=gt\&doc=IP/01/209|0|RAPI $\underline{D} \& \lg =\mathrm{EN}$

European Commission (2001b) Outcome of technical discussion with FIFA/UEFA on transfer systems, European Commission Press Release. IP/01/225, 16 February 2001. Available online at: http://europa.eu/rapid/start/cgi/guesten.ksh?p_action.gettxt=gt\&doc=IP/01/225|0|RAPI $\mathrm{D} \& \mathrm{lg}=\mathrm{EN}$

European Commission (2001c) Discussion with FIFA/UEFA on transfer systems, European Commission Press Release. IP/01/270, 27 February 2001. Available online at: http://europa.eu/rapid/start/cgi/guesten.ksh?p action.gettxt=gt\&doc=IP/01/270|0|RAPI $\underline{D} \& \lg =\mathrm{EN}$

European Commission (2001d) Outcome of discussions between the Commission and FIFA/UEFA on FIFA regulations on international football transfers, European Commission Press Release. IP/01/314, 5 March 2001. Available online at: http://europa.eu/rapid/pressReleasesAction.do?reference=IP/01/314\&format=HTML\& aged $=1$ \&language $=$ EN\&guiLanguage $=$ en

European Commission (2001e) Commission President Prodi Welcomes Outcome of Football Transfer Talks, European Commission Press Release. IP/01/320, 6 March 2001. 
Available online at:

http://europa.eu/rapid/start/cgi/guesten.ksh?p_action.gettxt=gt\&doc=IP/01/320|0|RAPI D\&lg=EN

European Commission (2002) Commission Closes Investigations into FIFA Regulations on International Football Transfers, European Commission Press Release. IP/02/824, 5 June 2002. Available online at:

http://europa.eu/rapid/pressReleasesAction.do?reference=IP/02/824\&format=HTML\& aged $=1$ \&language $=$ EN\&guiLanguage $=$ en

European Commission (2002b) Commission closes investigations into FIFA regulations on international football transfers, European Commission Press Release. IP/02/824, 5 June 2002. Available online at: http://europa.eu/rapid/pressReleasesAction.do?reference=IP/02/824\&format=HTML\& aged $=1$ \&language $=\mathrm{EN} \&$ guiLanguage $=\mathrm{en}$

European Commission (2009). World Anti-Doping Agency adopts revised data protection standard and continues successful dialogue with EU. IP/09/733.

European Commission (2012). Study on the Contribution of Sport to Economic Growth and Employment in the EU: Study commissioned by the European Commission, Directorate-General Education and Culture: Final Report. Brussels: European Commission.

European Council (1997) Declaration No. 29, on Sport, Attached to the Treaty of Amsterdam amending the Treaty on European Union, the Treaties establishing the European Communities and certain related acts.

FIFA (2001) Transfer negotiations between European Commission and football organisations finalised - Agreement over principles reached, Media Release. 5 March 2001.

FIFA (2009). FIFA and UEFA reject WADA ‘whereabouts' rule, Media Release, 24 March 2009.

https://www.fifa.com/aboutfifa/footballdevelopment/medical/media/news/newsid=104 0455/ [last accessed 30 April 2014].

FIFA (2013). Financial Report. FIFA: Zürich.

García, B. (2007) 'From regulation to governance and representation: Agenda-setting and the EU's involvement in sport', Entertainment and Sports Law Journal, 5 (1).

García, B and Meier, H E (2012) 'Limits of Interest Empowerment in the European Union: The Case Of Football', Journal of European Integration, 34 (4), 359-378. DOI: 10.1080/07036337.2011.611400

García, B. And Weatherill, S. (2012), Engaging with the EU in order to Minimise its Impact: Sport and the Negotiation of the Lisbon Treaty'. Journal of European Public Policy, Vol. 19, No. 2, pp. 238-256.

Geeraert, A. and Drieskens, E. (2015) 'The EU Controls FIFA and UEFA: a Principal-Agent Perspective'. Journal of European Public Policy, Vol. 22, No. 10, pp. 1448-1466.

Gradauskaite, J. (2010). The Advertising Appeal of Sports and the Legal Limits of the Incorporation of Sports in Advertising, Entertainment and Sports Law Journal, ISSN 1748-944X, June 2010, $<$ http://go.warwick.ac.uk/eslj/issues/volume8/number1/gradauskaite/>.

Grant-Braham, B. and Britton, J. (2012). 'Motor racing, tobacco company sponsorship, barcodes and alibi marketing.' Tobacco Control, 21:529-535.

Greenfield S and Osborn G (2001) Regulating football: Commodification, consumption and the law. Pluto Press, London

Halt, J. (2009). 'Where is the privacy in WADA's “Whereabouts” rule?' Marquette Sports Law Review, 20(1), 267-289.

Hanstad, D. V., Smith, A., and Waddington, I. (2008). 'The Establishment of the World Anti-Doping Agency A Study of the Management of Organizational Change and Unplanned Outcomes.' International review for the sociology of sport, 43(3), 227-249. 
Hanstad, D.V., Skille, A and Loland, S. (2010). Harmonisation of anti-doping work: Myth or reality? Sport in Society, 13, 418-430.

Hoek, J. and Sparks, R. (2000). Tobacco promotion restrictions: An international regulatory impasse? International Marketing Review, 17, 216-230.

Hopquin, B. (1995) 'Bruxelles presse l'UEFA de se soumettre à l'arret Bosman'. Le Monde, 25 December 1995

Houlihan, B. (2002). Dying to win: Doping in sport and the development of anti-doping policy. 2nd ed. Strasbourg: Council of Europe.

Houlihan, B. (2013). Achieving compliance in international anti-doping policy: An analysis of the 2009 World Anti-Doping Code. Sport Management Review. http://dx.doi.org/10.1016/j.smr.2013.10.002

Hunt, T.M. (2007). Sport, drugs, and the cold war: The conundrum of Olympic doping policy, 1970-1979. Olympika, 16, 19-42.

Hunt, T.M. (2011). Drug games: The International Olympic Committee and the politics of doping, 1960-2008. Austin: Texas University Press.

IOC (2013). Olympic Marketing Fact File. IOC: Lausanne.

Jacoby, W. and Meunier, S. (2010) 'Europe and the management of globalization', Journal of European Public Policy 17(3): 299-317.

Kelemen, D. (2010), „Globalizing European Union Environmental Policy, Journal of European Public Policy, 17/3, 335-349.

Kelemen, R. D. and Vogel, D. (2010), „Trading Places: The Role of the United States and the European Union in International Environmental Politics, "Comparative Political Studies, 43/4, 427-56.

Lanfranchi P and Taylor M (2001) Moving with the ball, the migration of professional footballers. Berg, Oxford

L'Equipe (2001) 'Bruxelles propose une rencontre au sommet'. L'Equipe, 2 February 2001.

MacGregor, O., Griffith, R., Ruggiu, D. and McNamee, M. (2013). Anti-doping, purported rights to privacy and WADA's whereabouts requirements: A legal analysis, Fair Play, $1(2), 13-38$.

Mamudu, H.M., and Studlar, D.T. (2009). 'Multilevel governance and shared sovereignty: European Union, member states, and the FCTC.' Governance, 22, 73-97.

Meier, H.E. and García, B. (2013) 'Abandoning hopes for veto power: institutional options for sport governing bodies in the European Union', International Journal of Sport Policy and Politics, 5 (3), 421-443. DOI: 10.1080/19406940.2012.656678

Meier, H.E. and García, B. (2015) 'Protecting Private Transnational Authority Against Public Intervention: FIFA's Power over National Governments'. Public Administration, online early view, DOI: 10.1111/padm.12208.

Meunier, S. and Nicolaïdis, K. (2006), „The European Union as a Conflicted Trade Power, Journal of European Public Policy, 13/6, 906-25.

Newman, A.L. (2008). Building transnational civil liberties: Transgovernmental entrepreneurs and the European Data Privacy Directive. International Organization, 62, 103-130.

Parrish, R. (2003) Sports Law and Policy in the European Union. Manchester: Manchester University Press.

Pielke, R. (2013) 'How can FIFA be held accountable?', Sport Management Review, 16, 255-267.

Prime Minister's Office (2000a) Press Briefing from the Prime Minister's Official Spokesman On: Football, Europe, Beef, Pay Review Bodies and Dome/Leaked Cabinet Minutes. 13 November 2000.

Prime Minister's Office (2000b) Joint Statement by the Prime Minister the Right Honourable Tony Blair MP and Chancellor Gerhard Schroeder. 9 September 2000.

Prime Minister's Office (2001a) Press briefing from the Prime Minister's spokesman On: Europe and Football Transfers. 30 January 2001. 
Prime Minister's Office (2001b) Press briefing from the Prime Minister's Spokesman On: Election Spending, Northern Ireland, Keith Vaz/Hammond Inquiry/M16, Steel, Dome, PM's Jacket and Schroeder/Europe. 30 January 2001.

Prime Minister's Office (2001c) Joint statement by the Prime Minister and Chancellor Gerhard Schroeder. 30 January 2001

PWC [Price Waterhouse Coopers] (2011). Changing the game: Outlook for the global sports market to 2015. http://www.pwc.com/sportsoutlook [last accessed 18 May 2014].

Rat der Europäischen Union (2012). Künftige Herausforderungen bei der Bekämpfung von Doping unter anderem im Freizeitsport. 8586/12 SPORT 22 DOPAGE SAN 76 JAI 236.

Reding, V. (2000) Commission's Investigation into FIFA's Transfer Rules, Statement to European Parliament, Strasbourg 7 September 2000. Speech/00/290. Available online at:

http://europa.eu/rapid/start/cgi/guesten.ksh?p_action.gettxt=gt\&doc=SPEECH/00/290| $0 \mid$ RAPID\&lg=EN

Roderick, M. (2006) The Work of Professional Football, a Labour of Love? Oxon: Routledge.

Shackleton, M. (2000). 'The politics of codecision.' Journal of Common Market Studies, 38(2), 325-342.

Slater, M. (2009). Legal threat to anti-doping code. BBC Sport, 22 January 2009. http://news.bbc.co.uk/sport2/hi/front_page/7844918.stm [last accessed 30 April 2014].

Sluggett, B. (2011). Sport's Doping Game: Surveillance in the Biotech Age, Sociology of Sport Journal, 28, 387-403

Smith, M.E. (2004). 'Toward a theory of EU foreign policymaking: Multi-level governance, domestic politics, and national adaptation to Europe's common foreign and security policy.' Journal of European Public Policy, 11, 740-758.

Smith, M.P. (2011). 'Single market, global competition: Regulating the European market in a global economy.' Journal of European Public Policy, 17, 936-953.

Tomlinson, A. (1983). 'Tuck up Tight Lads: Structures of Control within Football Culture' in A. Tomlinson (Ed.) Explorations in Football Culture. Eastbourne: Leisure Studies Association Publications, pp. 165-186.

Trainor, N. (2010). The 2009 WADA Code: A More Proportionate Deal for Athletes?, Entertainment and Sports Law Journal, June 2010, http://go.warwick.ac.uk/eslj/issues/volume8/num berl/trai nor/

UEFA (2000) Football pledges new dialogue on transfers, Media Release 179. 6 September 2000

Valkenburg, D., de Hon, Olivier, and van Hilvoorde, I. (2014). Doping control, providing whereabouts and the importance of privacy for elite athletes. International Journal of Drug Policy (2014), http://dx.doi.org/10.1016/j.drugpo.2013.12.013.

Vermeersch, A (2006). The European Union and the fight against doping in sport: on the field or on the sidelines? Entertainment and Sports Law Journal, April 2006, http://go.warwick.ac.uk/eslj/issues/volume4/number1/vermeersch/.

WADA (2003). World Anti-Doping Code. Montreal: WADA.

WADA (2008). International Standard for Testing. Montreal: WADA.

WADA (2009a). International Standard for the Protection of Privacy and Personal Information: June 2009 (Track changes). Montreal: WADA.

WADA (2009b). WADA Statement about the Opinion of European Working Party on Data Protection. Montreal: WADA.

WADA (2009c). Summary of comments of WADA to the European Working Party advisory opinion on the International Standard on the Protection of Privacy and Personal Information. Montreal: WADA. 
WADA (2009d). The Working Party on the protection of individuals with regard to the processing of personal data [Working Party opinion including WADA comments]. Montreal: WADA.

WADA (2009e). WADA Executive Committee approves enhanced International Data Protection Standard. 10 May, 2009. http://www.wada-ama.org/en/mediacenter/archives/articles/wada-executive-committee-approves-enhanced-internationaldata-protection-standard/ [last accessed 7 May 2014].

Waddington, I. (2010). Surveillance and control in sport: A sociologist looks at the WADA whereabouts system, International Journal of Sport Policy and Politics, 2, 255-274.

WPDP (2008). Opinion 3/2008 on the World Anti-Doping Code Draft International Standard for the Protection of Privacy. Brussels: Article 29 Data Protection Working Party.

WDPD (2009). Second opinion 4/2009 on the World Anti-Doping Agency (WADA) International Standard for the Protection of Privacy and Personal Information, on related provisions of the WADA Code and on other privacy issues in the context of the fight against doping in sport by WADA and (national) anti-doping organizations. Brussels: Article 29 Data Protection Working Party.

WPDP (2013). Contribution of the Article 29 Working Party to the 3rd stage of WADA's consultation in the context of the review of the World Anti-Doping Code and its International Standards. Ref. Ares(2013)289160.

Xue, H. and Mason, D.S. (2011). The changing stakeholder map of Formula One Grand Prix in Shanghai. European Sport Management Quarterly, 11, 371-395.

Young, A. R. and Peterson, J. (2013), „"We care about you, but.....” The Politics of EU Trade Policy and Development," Cambridge Review of International Affairs, http://dx.doi.org/10.1080/09557571.2012.734782.t

Young, A.R. (2007). The Politics of Regulation and the Internal Market. In K. E. Jørgensen, M.A. Pollack and B. Rosamond (eds), Handbook of European Union Politics, Sage, 373-94.

Young, A.R. (2009). Confounding Conventional Wisdom: Political not Principled Differences in the Transatlantic Regulatory Relationship. British Journal of Politics and International Relations, 11, 666-689.

Young, A.R. (2011). The rise (and fall?) of the EU's performance in the multilateral trading system. Journal of European Integration, 33, 715-729.

Young, A.R. and Peterson, J. (2006). The EU and the new trade politics. Journal of European Public Policy, 6, 795-814. 